\title{
PENALARAN SISWA DALAM MENYELESAIKAN SOAL LEVEL PROSES KOGNITIF EVALUASI PADA SUBMATERI MENGGAMBAR GRAFIK FUNGSI
}

\author{
Novita Anggraini \\ Pendidikan Matematika, FMIPA, Universitas Negeri Surabaya, E-mail: novitaanggraini1@mhs.unesa.ac.id
}

\author{
Abdul Haris Rosyidi \\ Pendidikan Matematika, FMIPA, Universitas Negeri Surabaya, E-mail: abdulharis@unesa.ac.id
}

\begin{abstract}
Abstrak
Penalaran merupakan keterampilan berpikir tingkat tinggi (Higher Order Thinking Skills). Proses kognitif yang termasuk dalam keterampilan berpikir tingkat tinggi salah satunya adalah evaluasi. Dalam menggambar grafik fungsi diperlukan adanya penalaran agar siswa tidak hanya menghafalkan prosedur menggambar grafik yang diajarkan oleh guru di sekolah. Proses kognitif evaluasi pada penelitian ini fokus pada proses memeriksa. Penelitian ini merupakan penelitian deskriptif kualitatif yang bertujuan untuk mendeskripsikan penalaran siswa dalam menyelesaikan soal level proses kognitif evaluasi pada submateri menggambar grafik fungsi. Pengumpulan data menggunakan dua metode yaitu tes dan wawancara. Subjek penelitian ini adalah 2 siswa yang benar menggambar grafik fungsi dan 2 siswa yang salah menggambar grafik fungsi. Data dianalisis berdasarkan hasil tes soal level evaluasi pada submateri menggambar grafik fungsi dan wawancara. Hasil penelitian menunjukkan bahwa: (1) Siswa yang benar menggambar grafik fungsi, dalam mengumpulkan fakta, siswa menyebutkan informasi yang tertulis dan tidak tertulis pada soal. Dalam membuat dugaan, siswa mengidentifikasi jenis fungsi untuk menduga bentuk grafik fungsi. Selain membuat dugaan, siswa juga memberikan alasan logis mengenai dugaan yang dibuat. Setelah memberikan alasan logis, siswa membuktikan dugaannya dengan menggambar grafik fungsi menggunakan langkahlangkah menggambar grafik dengan mengganti variabel pada fungsi dengan sebarang bilangan Real. Pada saat membuat kesimpulan, siswa memeriksa ketepatan perhitungan dalam menggambar grafik untuk memastikan jika kesimpulan yang akan dihasilkan benar, kemudian membuat kesimpulan dengan mengaitkan antara dugaan dengan bukti yang diperoleh, memvalidasi kesimpulan dengan cara menguji kesimpulan tersebut dengan soal lain yang sejenis. (2) Siswa yang salah menggambar grafik fungsi, dalam mengumpulkan fakta, siswa menyebutkan informasi tertulis, namun tidak menyebutkan informasi tidak tertulis. Dalam membuat dugaan, siswa mengidentifikasi jenis fungsi untuk menduga bentuk grafik fungsi. Selain membuat dugaan, ia juga memberikan alasan logis dari dugaan yang dibuat. Setelah memberikan alasan logis, siswa membuktikan dugaannya dengan menggambar grafik fungsi menggunakan langkahlangkah menggambar grafik dengan mengganti variabel pada fungsi dengan sebarang bilangan Real. Pada saat membuat kesimpulan, siswa memeriksa ketepatan perhitungan dalam menggambar grafik fungsi untuk memastikan kesimpulan yang dihasilkan benar. Pada saat memeriksa, siswa menemukan kesalahan dalam perhitungan dan letak titik pada bidang kartesius. Menurut siswa, kesalahan tersebut tidak berpengaruh pada hasil grafik fungsi. Membuat kesimpulan dengan mengaitkan antara dugaan dengan bukti yang diperoleh, pada saat membuat kesimpulan siswa menganggap benar bukti yang ia peroleh sehingga kesimpulan yang dibuat kurang tepat. Memvalidasi kesimpulan dengan cara menguji kesimpulan dengan soal lain yang sejenis.
\end{abstract}

Kata Kunci: Penalaran, Kognitif, Evaluasi, Grafik, Fungsi

\begin{abstract}
Reasoning is a Higher Order Thinking Skills (HOTS). Cognitive processes that are included in higher order thinking skills is evaluation. On drawing graph functions, reasoning is important, so that students not only memorize the routine procedures taught at school. This Research is a qualitative descriptive research that aim to describe the students' reasoning in solving the question of evaluation cognitive process level on drawing graph functions. The methods of data collections are test and interview. The subjects of this study are two students who did the drawing graph functions correctly and two students who did the drawing graph functions incorrectly. Data were analyzed based on the result of the evaluation cognitive process test about drawing graph functions. The results showed that: (1) Students who are drawing graph functions correctly, when gathering evidences, students mention written and unwritten information. When making conjecture, students identifying the type of function for assuming the shape of graph functions. After giving a logical
\end{abstract}


reason, students prove their conjecture by drawing graph function using routine steps. When making conclusion, students examine the accuracy of the calculations in drawing a graph to unsure that the conclusions that will be generated are correct, then draw a conclusions by linking the guesswork with the evidence obtained, validating the conclusions by testing these conclusions with other similar questions. (2) Students who are drawing the graph functions incorrectly, when gathering evidences, students mention written information, but did not mention the unwritten information. When making a conjecture, students identifying the type of function for assuming the shape a graph function. After that, students giving a logical reason to prove the conjecture that have been made, constructing a strategy to graph the functions to prove the conjecture that were made are correct, checking the accuracy of the calculation every step of graphing functions to be sure if the resulting conclusion is correct. At the time of checking the accuracy of steps to graph the functions, the students found a mistake in his calculation and put the points on the cartesian coordinates, he identifies an error had no effect on the outcome of the graph functions. Make a conclusion between conjecture and evidence obtained when making conclusions, students consider the evidence that they have obtained so that the conclusions made are incorrect. Validate the conclusions in a way to test conclusions with other similar problem, whether the conclusions made applies to the question.

Keywords: Reasoning, Cognitive, Evaluation, Graphs, Functions

\section{PENDAHULUAN}

Matematika merupakan salah satu disiplin ilmu yang mempunyai peranan penting dalam mengembangkan keterampilan bepikir manusia, salah satunya adalah penalaran. NCTM (2000) menyatakan lima standar kemampuan matematika yang harus dimiliki oleh siswa yaitu pemecahan masalah, komunikasi, koneksi, penalaran, dan representasi. Penalaran menjadi salah satu dari lima kompetensi matematika yang harus dimiliki oleh siswa, hal ini menunjukkan bahwa penalaran penting diajarkan dalam kelas matematika.

Ball dan Bass (2003:28) menyatakan, "the nation of mathematical understanding is meaningless without a serious emphasis on reasoning". Pernyataan tersebut mengungkapkan bahwa pemahaman terhadap matematika tak berarti tanpa melibatkan penalaran didalamnya. . Misalnya pemahaman perkalian bilangan desimal, siswa dapat menentukan letak koma dari hasil perkalian $0,7 \times$ $0,5=0,35$, akan tetapi mereka tidak mengetahui alasan mendasar prosedur tersebut bisa berjalan. Dengan menggunakan penalaran, siswa dapat menggunakan gagasan dan prosedur di dalam matematika secara fleksibel dan sesuai dengan masalah yang dihadapi.

Pentingnya penalaran di atas masih belum diimbangi dengan hasil yang memuaskan. Penalaran siswa Indonesia masih sangat rendah, hal ini dapat terindikasi dari hasil studi TIMSS (Trends in International Mathematics and Science Study) pada tahun 2015 yang diikuti oleh siswa kelas VIII SMP, Indonesia berada pada peringkat 36 dari 49 negara (Rahmawati,2016).

Menurut Brookhart (2010), penalaran (reasoning) merupakan salah satu keterampilan berpikir tingkat tinggi. Menurut Anderson\& Krathwohl (2001) domain proses kognitif yang termasuk dalam keterampilan berpikir tingkat tinggi yaitu analisis (analyze), evaluasi (evaluate), dan mencipta (create). Sehingga dapat disimpulkan bahwa salah satu domain proses kognitif dalam penalaran yaitu level proses kognitif evaluasi. Evaluasi dibutuhkan seseorang tidak hanya dalam belajar matematika, akan tetapi berguna juga dalam kehidupan sehari-hari, dengan evaluasi seseorang dapat menilai keefektifan suatu hasil yang didapatkannya, dapat pula menilai apakah cara yang dilakukan seseorang untuk menyelesaikan masalah telah menghasilkan sesuatu yang dikehendaki, namun kenyataan yang ada level proses kognitif evaluasi siswa Indonesia masih sangat rendah. Hal ini terlihat pada penelitian yang dilakukan oleh Ardhana (2017) yang menyatakan bahwa kemampuan mengevaluasi siswa masih sebesar $0 \%$ dalam menyelesaikan soal garis dan sudut. Sehingga, berdasarkan pernyataan tersebut kemampuan siswa dalam mengevaluasi perlu ditingkatan.

Lampiran Permendikbud Nomor 68 tentang Standar Proses Pendidikan Dasar Dan Menengah Kurikulum 2013 ada 3 ranah kompetensi yang dikembangkan dalam pelajaran matematika yaitu ranah sikap, ranah pengetahuan dan ranah keterampilan. Untuk keterampilan diperoleh melalui aktivitas mengamati, menanya, mencoba, menalar, menyaji, dan mencipta. Salah satu submateri yang berhubungan dengan ranah keterampilan adalah submateri menggambar grafik fungsi. Wardhani (2010) menyebutkan menyajikan pernyataan matematika dengan lisan, tertulis, tabel, gambar, atau diagram merupakan indikator yang menunjukkan adanya komunikasi. Brodie (2010) menyebutkan bahwa komunikasi merupakan bagian untuk melengkapi proses penalaran. Berdasarkan kedua pernyataan tersebut, dapat dikatakan ketika siswa menghasilkan gambar grafik fungsi, maka hasil gambar yang ia berikan merupakan wujud dari melengkapi penalaran yang ia lakukan.

Berdasarkan uraian di atas, peneliti tertarik untuk melakukan penelitian tentang bagaimana penalaran siswa dalam menyelesaikan soal level proses kognitif evaluasi pada submateri menggambar grafik fungsi, sehingga 
disusunlah sebuah penelitian yang berjudul, "Penalaran Siswa dalam Menyelesaikan Soal Level Proses Kognitif Evaluasi pada Submateri Menggambar Grafik Fungsi”.

\section{Penalaran}

Menurut Keraf (1982), penalaran merupakan proses berpikir yang berusaha menghubungkan fakta-fakta yang diketahui menuju pada suatu kesimpulan. Menurut Copi (1978), penalaran merupakan salah satu jenis berpikir untuk menarik suatu kesimpulan, dimana kesimpulan tersebut diambil dari pernyataan-pernyataan baru yang dapat bernilai benar atau dianggap benar. Berdasarkan definisi penalaran yang diberikan dua ahli seperti yang diuraikan di atas, maka dapat disimpulkan bahwa penalaran adalah suatu proses berpikir dalam menarik suatu kesimpulan yang didasarkan pada suatu ketentuanketentuan, fakta-fakta dan pernyataan yang benar atau dianggap benar.

\section{Level Proses Kognitif Evaluasi dalam Taksonomi Bloom}

Taksonomi Bloom revisi mengategorikan tujuan pendidikan ditinjau dari dua dimensi yaitu dimensi proses kognitif dan dimensi pengetahuan (Anderson \&Krathwohl,2001). Dimensi proses kognitif meliputi enam kategori yaitu mengingat, memahami, mengaplikasikan, menganalisis, mengevaluasi, dan mencipta. Salah satu proses kognitif dalam revisi Taksonomi Bloom yaitu mengevaluasi. Menurut Anderson\& Krathwohl (2001:68), mengevaluasi diartikan sebagai tindakan membuat suatu penilaian (judgments) yang didasarkan pada kriteria dan standar tertentu. Kriteria yang digunakan adalah kualitas, efektifitas, efisiensi, dan konsistensi. Menurut Anderson\& Krathwohl (2001:63), "The category evaluate includes the cognitive processes of checking (judgments about the internal consistency) and critiquing (judgments based on external criteria)". Hal ini berarti ada dua macam proses kognitif yang tercakup dalam kategori evaluasi, yaitu memeriksa dan mengkritisi. Fokus pada penelitian ini yaitu proses kognitif evaluasi tipe memeriksa.

\section{Menggambar Grafik Fungsi}

NCTM (2000) menyatakan bahwa untuk memahami dan menggunakan ide-ide matematika, sering kali ide-ide tersebut direpresentasikan melalui gambar, benda nyata, tabel, grafik, bilangan, dan simbol-simbol, dll. Menurut Varberg dan Purcell (2010:50), ketika daerah asal dan daerah hasil dari suatu fungsi merupakan bilangan real, fungsi tersebut dapat digambar grafiknya pada bidang koordinat. Hal ini berarti fungsi yang merupakan salah satu bagian dari ide-ide matematika yang dapat disajikan ke dalam gambar grafik yang didefinisikan sebagai representasi dari himpunan penyelesaian suatu fungsi.
Untuk menemukan himpunan penyelesaian suatu fungsi, cara yang dapat digunakan adalah dengan melakukan substitusi beberapa nilai $x$ ke dalam $f(x)$. Nilai $x$ sebagai absis dan nilai $f(x)$ sebagai nilai $y$ atau sama dengan ordinat, sehingga diperoleh himpunan koordinat titik-titik yang bersesuaian antara $x$ dan nilai $f(x)$.

Tabel 1 Penyajian Nilai $x, f(x)$ dan koordinat $(x, f(x))$

\begin{tabular}{|c|l|l|l|l|l|l|l|l|}
\hline$x$ & & & & & & & & \\
\hline$f(x)$ & & & & & & & & \\
\hline$(x, f(x))$ & & & & & & & & \\
\hline
\end{tabular}
$(x, f(x))$ digambar pada bidang koordinat. Langkah terakhir, titik-titik tersebut dihubungkan satu sama lain membentuk sebuah garis lurus dalam fungsi linear.

Penalaran dalam Menyelesaikan Soal Level Proses Kognitif pada Submateri Menggambar Grafik Fungsi Menurut Brookhart (2010), penalaran merupakan salah satu keterampilan berpikir tingkat tinggi. Keterampilan berpikir tingkat tinggi menurut Anderson\& Krathwohl (2001) meliputi domain proses kognitif analisis (analyze), evaluasi (evaluate), dan mencipta (create). Sehingga penalaran mencakup level kognitif analisis, evaluasi dan mencipta. Dalam penelitian ini level proses kognitif yang digunakan adalah level evaluasi tipe memeriksa.

Indikator dalam penelitian ini yaitu diadaptasi dari English (2004), diantaranya mengumpulkan fakta, menganalisis data, membuat dugaan, membangun argumen, membuat dan memvalidasi kesimpulan. Setelah dikaitkan dengan proses kognitif evaluasi tipe memeriksa, maka indikator penelitian ini yaitu:

Tabel 1. Indikator Penalaran dalam Menyelesaikan Soal

\begin{tabular}{|c|l|}
\hline $\begin{array}{c}\text { Indikator } \\
\text { Penalaran }\end{array}$ & $\begin{array}{c}\text { Indikator penalaran dalam } \\
\text { menyelesaikan soal level kognitif } \\
\text { evaluasi tipe memeriksa }\end{array}$ \\
\hline $\begin{array}{c}\text { Mengumpulkan } \\
\text { Fakta }\end{array}$ & $\begin{array}{l}\text { Mengidentifikasi informasi yang } \\
\text { terdapat pada soal }\end{array}$ \\
\hline $\begin{array}{c}\text { Menganalisis } \\
\text { Data }\end{array}$ & $\begin{array}{l}\text { Menemukan informasi yang tidak } \\
\text { tertulis pada soal }\end{array}$ \\
\hline $\begin{array}{c}\text { Membuat } \\
\text { Dugaan }\end{array}$ & $\begin{array}{l}\text { Mengidentifikasi jenis fungsi } \\
\text { dengan memperhatikan } \\
\text { fakta/informasi yang dikumpulkan }\end{array}$ \\
\hline $\begin{array}{c}\text { Membangun } \\
\text { Argumen }\end{array}$ & $\begin{array}{l}\text { Memberikan alasan logis dan } \\
\text { membuktikan dugaanya. }\end{array}$ \\
\hline Membuat & $\begin{array}{l}\text { Merumuskan kesimpulan akhir } \\
\text { berdasarkan langkah-langkah yang } \\
\text { telah dilakukan }\end{array}$ \\
\hline $\begin{array}{c}\text { Kesimpulan } \\
\text { Kesimpulan }\end{array}$ & $\begin{array}{l}\text { Menguji kesimpulan dengan soal } \\
\text { lain yang sejenis }\end{array}$ \\
\hline
\end{tabular}

\section{METODE}

Penelitian ini merupakan penelitian deskriptif dengan pendekatan kualitatif. Penelitian ini dilaksanakan di kelas 
VIII F SMP Negeri 3 Taman Sidoarjo dengan 34 siswa. Dari 34 siswa, dipilih 4 subjek yang terdiri dari 2 siswa yang benar menggambar grafik fungsi dan 2 siswa yang salah dalam menggambar grafik fungsi. Untuk menentukan subjek yang terpilih dalam penelitian ini, 34 siswa diberikan tes soal level kognitif evaluasi (C5), selanjutnya peneliti mengelompokkan hasil tes berdasarkan dua kriteria yang ditentukan yaitu: (1) siswa yang benar menggambar grafik fungsi dan (2) siswa yang salah menggambar grafik fungsi. Dalam menentukan banyaknya subjek pada setiap kriteria, peneliti memperhatikan keberagaman jawaban subjek, sehingga jumlah subjek bergantung pada ragam jawaban subjek pada setiap kriteria. Setelah peneliti mengelompokkan hasil tes soal $\mathrm{C} 5$, peneliti memilih 4 subjek untuk diwawancarai guna mengetahui proses berpikir subjek dalam menyelesaikan tes soal C5. Selanjutnya hasil tes dan wawancara dianalisis berdasarkan indikator yang digunakan dalam penelitian ini. Berikut adalah tes soal C5 yang diberikan kepada siswa.

1. Diberikan fungsi sebagai berikut:

i. $f(x)=\frac{7}{4}\left(\begin{array}{ll}4 & x\end{array}\right)+1, x \in$

ii. $g(x)=\frac{3 x+k}{3}+\frac{k}{2}, x \in, k=$ konstanta

iii. $(x)=\frac{-x+21}{3} \quad \frac{(1 \& 6 x)}{6}, x \in$

a. Tanpa menggambar dan menyederhanakan ketiga fungsi di atas, dugalah bentuk grafik dari ketiga fungsi di atas! Jelaskan alasanmu!

b. Buktikan dugaanmu pada nomer 1.a dengan menggambar grafik fungsi

$(x)=\frac{-x+21}{3} \quad \frac{(18+6 x)}{6}, x \in R \quad$ beserta langkah-langkahnya!

Gambar 1. Soal C5 yang Diberikan kepada Siswa

\section{HASIL DAN PEMBAHASAN}

Tes soal C5 diberikan kepada 34 siswa kelas VIII-F SMP Negeri 3 Taman Sidoarjo. Berdasarkan data tes soal level proses kognitif evaluasi (C5) diperoleh 4 subjek penelitian, berikut subjek penelitian yang terpilih.

Tabel 2. Subjek Penelitian

\begin{tabular}{|c|c|l|}
\hline No. & $\begin{array}{c}\text { Insial } \\
\text { Nama }\end{array}$ & \multicolumn{1}{|c|}{ Keterangan } \\
\hline 1. & DAF & $\begin{array}{l}\text { Siswa yang benar menggambar } \\
\text { grafik fungsi dengan cara } \\
\text { memasukkan sebarang nilai } \boldsymbol{x} \\
\text { untuk mencari nilai } \boldsymbol{y} \text { tanpa } \\
\text { menyederhanakan fungsi yang }\end{array}$ \\
\hline
\end{tabular}

\begin{tabular}{|c|c|l|}
\hline No. & $\begin{array}{c}\text { Insial } \\
\text { Nama }\end{array}$ & \multicolumn{1}{|c|}{ Keterangan } \\
\hline 2. & $\begin{array}{c}\text { SRB } \\
\text { (SB2) }\end{array}$ & $\begin{array}{l}\text { Siswa yang benar menggambar } \\
\text { grafik fungsi dengan cara } \\
\text { menyederhanakan fungsi yang } \\
\text { diberikan, lalu memasukkan } \\
\text { sebarang nilai } \boldsymbol{x} \text { pada fungsi } \\
\text { yang sederhana untuk mencari } \\
\text { nilai } \boldsymbol{y} \text {. }\end{array}$ \\
\hline 3. & $\begin{array}{l}\text { Siswa yang salah dalam } \\
\text { menggambar grafik fungsi, } \\
\text { letak kesalahannya terdapat }\end{array}$ \\
\hline 4. & $\begin{array}{l}\text { OBD } \\
\text { pada operasi hitungnya. }\end{array}$ \\
\hline SS2) & $\begin{array}{l}\text { Siswa yang salah dalam } \\
\text { menggambar grafik fungsi, } \\
\text { letak kesalahannya yaitu saat } \\
\text { meletakkan titik pada bidang } \\
\text { koordinat kartesius. }\end{array}$ \\
\hline
\end{tabular}

1. Penalaran Siswa yang Benar Menggambar Grafik Fungsi Linear

a) Penalaran Subjek Benar Pertama (SB1) dalam Menggambar Grafik Fungsi

Siswa mengumpulkan fakta/informasi tertulis pada soal. Ketika mengumpulkan fakta, ia memeriksa fungsi dan memperhatikan pangkat tertinggi variabel pada fungsi, selain itu siswa menyebutkan simbol-simbol pada soal dan menyebutkan hubungan variabel $\boldsymbol{x}$ dengan nilai fungsinya.

Siswa mengumpulkan fakta/informasi yang tidak tertulis dengan menganalisis pola rumus fungsi pada soal. Siswa menemukan bahwa fungsi pada soal memiliki keteraturan pola pada rumus fungsinya.

$$
\begin{aligned}
& \text { a. Bentuk grafile fungsi ralah garis lurus. Kareng, } \\
& \text { variabelnya berpangkat satu. } \\
& \text { PSB1-01 : Berdasarkan jawabanmu, kamu } \\
& \text { menduga bahwa bentuk grafik } \\
& \text { fungsi pada soal adalah garis lurus, } \\
& \text { mengapa kamu membuat dugaan } \\
& \text { seperti ini? } \\
& \text { SB1-01 : Karena variabelnya berpangkat } 1
\end{aligned}
$$

Gambar 2. Jawaban Siswa Saat Membuat Dugaan

Membuat dugaan dengan mengidentifikasi jenis fungsi untuk menduga bentuk grafik fungsinya. Dugaan ini ia peroleh dari mengaitkan antara fakta yang dikumpulkan dan pengetahuan yang dimilikinya. Hal ini sesuai menurut Rahmawati (2014) yang menunjukkan bahwa 
ketika seseorang diminta untuk menduga grafik fungsi maka hal yang dilakukan pertama adalah mengidentifikasi jenis fungsi. Berikut jawaban dan cuplikan wawancara siswa saat membuat dugaan

Siswa yang benar menggambar grafik fungsi, memberikan alasan logis mengenai dugaan yang dibuat. Berikut hasil wawancara dengan siswa saat membuat alasan logis.

\section{PSB1-03 : Dari ketiga fungsi pada soal, fungsi mana yang memiliki variabel berpangkat 1 ? \\ SB1-03 : Semua fungsi bu, walaupun $x$-nya ada dua \\ PSB1-04 : $x$-nya ada dua bagaimana? \\ SB1-04 :Kan $\boldsymbol{h}(\boldsymbol{x})$ ada $2 \boldsymbol{x}$-nya bu, tapi kalau dikurangi sama $\boldsymbol{x}$ nanti hasilnya $\boldsymbol{x}$-nya jadi 1 , jadi pangkat variabel $\boldsymbol{x}$ tetap 1 \\ PSB1-05: Lalu mengapa jika variabelnya berpangkat 1 bentuk grafiknya garis lurus? \\ SB1-05 : Karena fungsi linear maka grafiknya garis lurus}

Selain memberikan alasan logis, siswa mebuktikan dugaannya dengan menggambar grafik. Cara yang digunakan yaitu mensubstitusikan sebarang bilangan Real pada fungsi. Siswa mengganti variabel dengan suatu nilai untuk mencari koordinat titiknya, kemudian meletakkan titik pada bidang kartesius, menghubungkan kedua titik, sehingga diperoleh gambar suatu grafik fungsi. Berikut hasil jawaban siswa saat menggambar grafik fungsi.

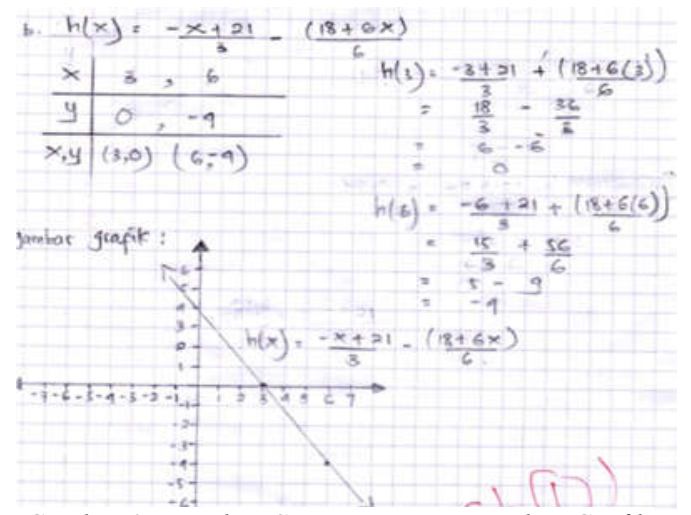

Gambar 3. Jawaban Siswa saat Menggambar Grafik

Siswa membuat kesimpulan dengan memeriksa setiap langkah penyelesaian (perhitungan dan letak titik pada bidang kartesius). Siswa memastikan tidak ada kesalahan pada langkah dan gambar grafik yang dihasilkan, saat memeriksa ia menemukan ide baru yaitu memasukkan nilai $\boldsymbol{x}=\mathbf{0}$ lain untuk mencocokkan apakah grafik yang dihasilkan benar. Hal ini sesuai Brodie (2010). Ia mengatakan bahwa dalam penalaran matematika bagian terpenting adalah siswa datang dengan ide-ide dari dirinya sendiri. Setelah memeriksa semua langkah, siswa membuat kesimpulan dengan mengaitkan dugaan dan grafik fungsi yang dihasilkan. Berikut adalah hasil wawancara dengan siswa saat membuat kesimpulan.

$$
\begin{array}{ll}
\text { PSB1-58: } & \text { Lalu, kesimpulan apa yang dapat } \\
& \text { kamu buat berdasarkan dugaan } \\
& \text { dan buktimu tadi? } \\
\text { SB1-58 : } & \text { Kan dugaan saya tadi bentuknya } \\
& \text { garis lurus, terus buktinya juga } \\
& \text { hasilnya garis lurus. Berarti } \\
& \text { kesimpulannya garis lurus bu }
\end{array}
$$

Siswa memvalidasi kesimpulan yang telah dibuat dengan menguji kesimpulan tersebut untuk soal lain yang sejenis. Berikut adalah hasil wawancara dengan siswa saat memvalidasi kesimpulan.

PSB1-61 : Apakah kesimpulanmu dapat berlaku untuk soal ini?

Dugalah bentuk grafik fungsi dari

$(x)=\frac{1}{2} x+4$ !

SB1-61 : Garis lurus bu

PSB1-62 : Mengapa?

SB1-62 :Karena itu fungsi linear, variabel $\boldsymbol{x}$ berpangkat 1

b) Penalaran Subjek Benar Kedua (SB2) dalam Menggambar Grafik Fungsi

Siswa yang benar menggambar grafik fungsi mengumpulkan fakta/informasi tertulis pada soal. Ketika mengumpulkan fakta, siswa memeriksa fungsi dan memperhatikan pangkat tertinggi variabel pada fungsi, selain itu siswa menyebutkan simbol-simbol pada soal, namun siswa tidak menyebutkan hubungan antar variabel pada fungsi.

Siswa yang benar menggambar grafik fungsi, mengumpulkan fakta/informasi yang tidak tertulis dengan menganalisis pola rumus fungsi pada soal. Siswa menemukan bahwa 
fungsi pada soal memiliki keteraturan pola pada rumus fungsinya.

Siswa yang benar menggambar grafik fungsi, membuat dugaan dengan mengidentifikasi jenis fungsi untuk menduga bentuk grafik fungsinya. Dugaan ini ia peroleh dari mengaitkan antara fakta yang dikumpulkan dan pengetahuan yang dimilikinya. Hal ini sesuai menurut Rahmawati (2014) yang menunjukkan bahwa ketika seseorang diminta untuk menduga grafik fungsi maka hal yang dilakukan pertama adalah mengidentifikasi jenis fungsi. Berikut jawaban dan cuplikan wawancara siswa saat membuat dugaan.

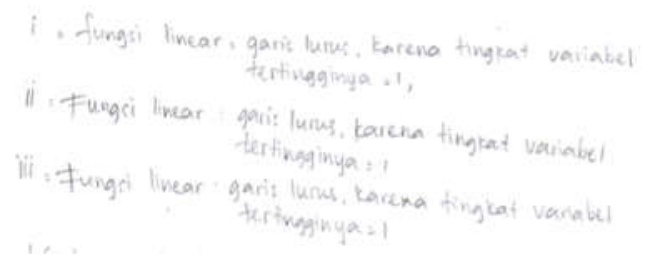

Gambar 4. Jawaban Siswa dalam Membuat Dugaan

$$
\begin{array}{ll}
\text { PSB2-01 : Tanpa menggambar dan } \\
\\
\begin{array}{l}
\text { menyederhanakan ketiga fungsi, apa } \\
\text { dugaanmu? }
\end{array} \\
\text { SB1-01 Dugaanku bentuk grafiknya garis } \\
\text { lurus } \\
\text { PSB2-02 : Mengapa kok garis lurus? } \\
\text { SB2-02 : Karena fungsi pada soal adalah fungsi }
\end{array}
$$

Siswa memberikan alasan logis mengenai dugaan yang dibuat. Berikut hasil wawancara dengan siswa saat memberikan alasan logis.

\section{PSB2-03 : Mengapa kamu yakin kalau ketiga fungsinya linear? \\ SB1-03 : Pangkat tertinggi variabel ini 1 \\ PSB2-02 : Kamu tau apa itu fungsi linear? \\ SB2-02 : Fungsi yang memiliki pangkat tertinggi variabelnya 1}

Selain memberikan alasan logis, siswa membuktikan dugaannya dengan menggambar grafik fungsinya dengan cara mensubstitusikan sebarang bilangan Real pada variabel fungsi. Langkah-langkah menggambar yaitu siswa menyederhanakan fungsi dengan menyamakan penyebutnya, kemudian ia mengganti variabel dengan suatu nilai untuk mencari koordinat titiknya, kemudian meletakkan koordinat titik pada bidang kartesius, menghubungkan dua titik koordinat, sehingga diperoleh gambar suatu grafik fungsi. Berikut hasil jawaban siswa saat menggambar grafik fungsi.

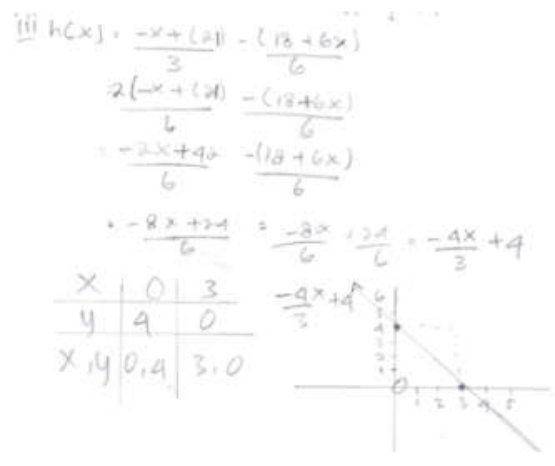

Gambar 5. Jawaban Siswa saat Menggambar Grafik Fungsi

Siswa membuat kesimpulan dengan memeriksa setiap langkah penyelesaian (perhitungan dan letak titik pada bidang kartesius). Siswa memastikan tidak ada kesalahan pada langkah dan gambar grafik yang dihasilkan. Setelah memeriksa semua langkah, siswa membuat kesimpulan dengan mengaitkan dugaan dan grafik fungsi yang dihasilkan. Berikut adalah hasil wawancara dengan siswa saat membuat kesimpulan.

$$
\begin{aligned}
\text { PSB2-42 : } & \text { Coba buatlah kesimpulan setelah } \\
& \text { kamu membuat dugaan dan } \\
& \text { membuktikannya! } \\
\text { SB2-42 }: & \text { Kesimpulan saya, fungsi linear } \\
& \text { itu memiliki grafik berbentuk } \\
& \text { garis lurus. Fungsi linear dapat } \\
& \text { dilihat dari pangkat tertinggi dari }
\end{aligned}
$$

Siswa memvalidasi kesimpulan yang telah dibuat dengan menguji kesimpulan tersebut untuk soal lain yang sejenis. Berikut adalah hasil wawancara dengan siswa saat memvalidasi kesimpulan.

$\begin{array}{ll}\text { PSB2-43 } & \text { : Kalau bu Novi punya soal gini } \\ & \boldsymbol{f}(\boldsymbol{x})=\mathbf{2} \boldsymbol{x}+\mathbf{4}, \quad \text { tanpa } \\ & \text { menggambar, gambar grafiknya } \\ & \text { berupa apa? } \\ \text { SB2-43 } & \text { :Ya garis lurus bu } \\ \text { PSB2-44 } & \text { :Mengapa hasilnya garis lurus? } \\ \text { SB2-44 } & : \text { Karena itu fungsi linear dan } \\ & \text { fungsi linear hasil grafiknya } \\ \text { PSB2-45 } & \text { berupa garis lurus bu. } \\ & \text { :Ohh begitu, berarti apakah } \\ & \text { kesimpulan yang kamu buat tadi } \\ & \text { sudah benar? }\end{array}$




\section{Penalaran Siswa yang Salah Menggambar Grafik} Fungsi Linear

a) Penalaran Subjek Salah Pertama (SS1) dalam Menggambar Grafik Fungsi

Siswa yang salah menggambar grafik fungsi mengumpulkan fakta/informasi tertulis pada soal. Ketika mengumpulkan fakta, ia memeriksa fungsi dan memperhatikan pangkat tertinggi variabel pada fungsi, siswa tidak menyebutkan simbol-simbol pada soal dan tidak menyebutkan hubungan variabel $\boldsymbol{x}$ dengan nilai fungsinya.

Siswa tidak mengumpulkan fakta/informasi yang tidak tertulis. Siswa tidak bisa menemukan keterkaitan antara bentuk rumus fungsi dengan bentuk umum fungsi linear, sehingga ia tidak menemukan pola rumus fungsi pada soal.

Siswa membuat dugaan dengan mengidentifikasi jenis fungsi untuk menduga bentuk grafik fungsinya. Dugaan ini ia peroleh dari mengaitkan antara fakta yang dikumpulkan dan pengetahuan yang dimilikinya. Hal ini sesuai menurut Rahmawati (2014) yang menunjukkan bahwa ketika seseorang diminta untuk menduga grafik fungsi maka hal yang dilakukan pertama adalah mengidentifikasi jenis fungsi. Berikut jawaban dan cuplikan wawancara siswa saat membuat dugaan.

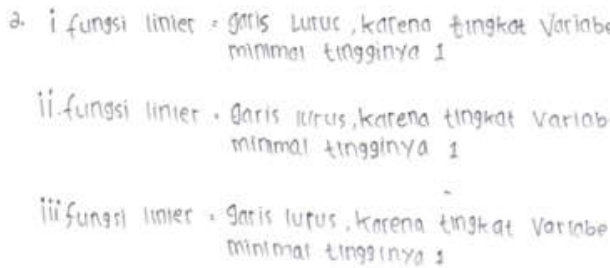

Gambar 6 Jawaban Siswa dalam Membuat Dugaan

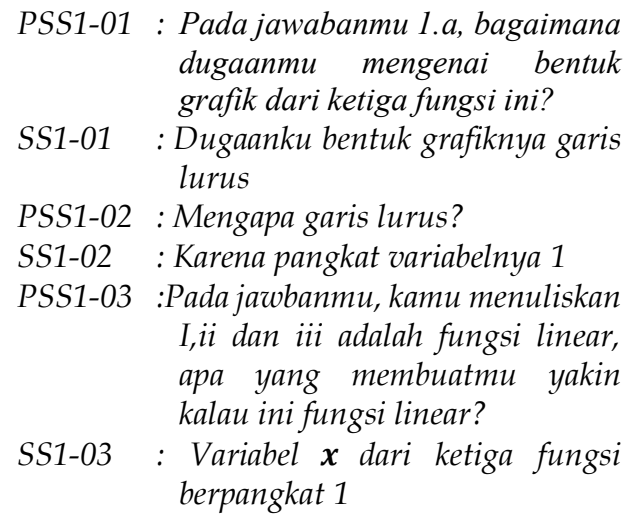

Berdasarkan kutipan wawancara siswa yang salah di atas, terlihat bahwa siswa mampu menduga bentuk grafik dan mampu mengemukakan alasannya atas dugaan yang dibuat. Siswa beralasan bahwa tiga fungsi pada soal adalah fungsi linear, sehingga grafik fungsinya adalah garis lurus.

Selain memberikan alasan logis, siswa membuktikan dugaannya dengan menggambar grafik fungsi $\boldsymbol{h}(\boldsymbol{x})$. Siswa menyederhanakan fungsi dengan menyamakan penyebutnya, kemudian ia mengganti variabel dengan dua nilai yang berbeda untuk mencari koordinat titiknya, kemudian meletakkan koordinat titik pada bidang. Pada saat mencari koordinat titik $(\boldsymbol{x}, \boldsymbol{y})$, siswa mengalami kesalahan perhitungan, sehingga titik koordinat yang diperoleh kurang

tepat. Kesalahan perhitungan ini juga

dikemukakan oleh Fatimah (2017). Menurutnya, salah satu kesalahan dalam menyelesaikan soal tentang persamaan garis lurus terletak pada

kesalahan menghitung dalam operasi penjumlahan, pengurangan, perkalian dan pembagian

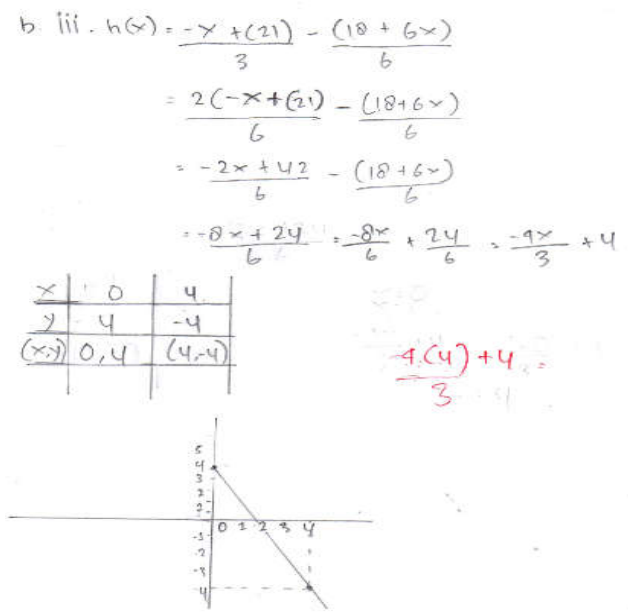

Gambar 7 Jawaban Siswa saat Menggambar Grafik

Siswa yang salah menggambar grafik fungsi membuat kesimpulan dengan memeriksa setiap langkah penyelesaian (perhitungan dan letak titik koordinatnya). Siswa menemukan kesalahan pada saat mencaari koordinat $(\boldsymbol{x}, \boldsymbol{y})$, ia mengatakan letak kesalahan terjadi saat ia memasukkan $\boldsymbol{x}=\mathbf{4}$ pada fungsi, sehingga koordinat yang dihasilkan kurang tepat. Pada langkah ini, siswa membenarkan jawabannya. Berikut adalah kutipan wawancara siswa.

Walaupun siswa mengalami kesalahan dalam menghitung, ia tetap membuat kesimpulan. Menurutnya, kesalahan perhitungan tersebut tidak berpengaruh pada bentuk grafiknya. Menurut siswa, grafik fungsi linear tetap garis lurus. Hal ini menunjukkan bahwa 
siswa tidak memahami konsep grafik dari suatu fungsi, dimana grafik suatu fungsi adalah representasi himpunan penyelesaian dari fungsi tersebut. Jika himpunan penyelesaian suatu koordinat $(\boldsymbol{x}, \boldsymbol{y})$ tidak tepat maka grafik yang dihasilkan bukan merupakan representasi himpunan dari fungsi tersebut.

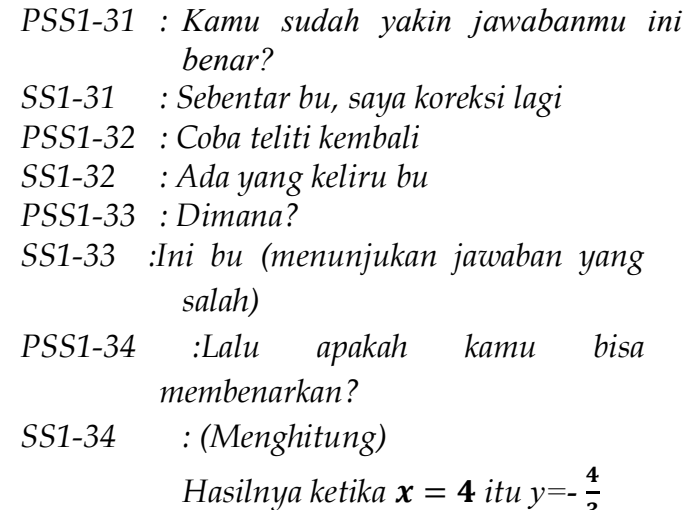

Siswa menilai jika dugaan yang dihasilkan benar karena fungsi yang diberikan adalah fungsi linear, hasil grafik yang dihasilkan juga garis lurus walaupun ada kesalahan pada perhitungan, berdasarkan kesimpulan yang dibuat oleh siswa, maka ia mencoba untuk memvalidasi kesimpulan yang dibuat dengan menguji kesimpulan tersebut untuk soal lain yang sejenis. Berikut adalah hasil wawancara dengan siswa saat memvalidasi kesimpulan.

PSS1-52 : Lalu, kalau saya punya soal "Dugalah bentuk grafik fungsi dari $f(x)=2 x+4$

SS1-52 : Mudah, ya jelas garis lurus

PSS1-53 : Mengapa?

SS1-53 : Karena fungsinya linear, dilihat dari pangkat $x$-nya.

b) Penalaran Subjek Salah Kedua (SS2) dalam Menggambar Grafik Fungsi

Siswa yang salah menggambar grafik fungsi dapat mengumpulkan fakta/informasi tertulis pada soal. Ketika mengumpulkan fakta, ia memeriksa fungsi dan memperhatikan pangkat tertinggi variabel pada fungsi, namun siswa tidak menyebutkan simbol-simbol pada soal dan tidak menyebutkan hubungan variabel $\boldsymbol{x}$ dengan nilai fungsinya.

Siswa tidak mengumpulkan fakta/informasi yang tidak tertulis. Siswa tidak bisa menemukan keterkaitan antara bentuk rumus fungsi pada soal dengan bentuk umum fungsi linear.

Siswa membuat dugaan dengan mengidentifikasi jenis fungsi untuk menduga bentuk grafik fungsinya. Dugaan ini ia peroleh dari mengaitkan antara fakta yang dikumpulkan dan pengetahuan yang dimilikinya. Hal ini sesuai menurut Rahmawati (2014) yang menunjukkan bahwa ketika seseorang diminta untuk menduga grafik fungsi maka hal yang dilakukan pertama adalah mengidentifikasi jenis fungsi. Berikut jawaban dan cuplikan wawancara siswa saat membuat dugaan.

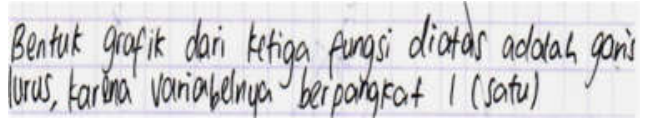

Gambar 8. Jawaban Siswa saat Membuat Dugaan.

PSS2-01 : Pada lembar jawabanmu, tertulis bahwa bentuk grafik dari ketiga fungsi yang diberikan adalah garis lurus. Apa alasanmu membuat dugaan seperti itu?

SS2-01 : Karena variabelnya berpangkat 1

PSS2-02 : Mengapa kalau berpangkat 1 grafiknya berbentuk garis lurus?

SS2-02 : Karena fungsinya ini fungsi linear bu

Berdasarkan hasil wawancara di atas, nampak bahwa siswa memberikan alasan atas dugaan yang dibuat. Menurutnya, grafik fungsi pada soal adalah garis lurus, karena fungsi tersebut adalah fungsi linear, hal ini ditunjukkan dengan pangkat tertinggi variabelnya adalah 1

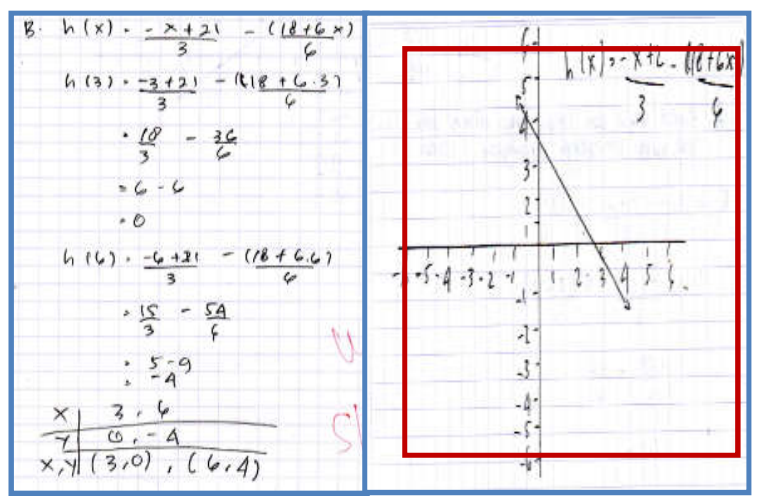

Gambar 9 Jawaban Siswa saat Menggambar Grafik

Selain memberikan alasan logis, siswa mebuktikan dugaannya dengan menggambar grafik dengan langkah-langkah rutin. Langkah 
pertama yaitu mencari koordinat $(\mathrm{x}, \mathrm{y})$ dengan mengganti variabel $\mathrm{x}$ dengan dua nilai $\mathrm{x}$ yang berbeda, kemudian meletakkan koordinat titik pada bidang. Pada saat meletakkan titik koordinat $(\mathrm{x}, \mathrm{y})$, siswa mengalami kesalahan sehingga grafik yang dihasilkan bukan merupakan representasi himpunan penyelesaian dari fungsi. Berikut adalah hasil jawaban pada saat menggambar grafik fungsi.

Siswa membuat kesimpulan dengan memeriksa setiap langkah penyelesaian (perhitungan dan letak titik koordinatnya). Siswa menemukan kesalahan pada gambar grafik yang dihasilkan, menurutnya, titik koordinat pada gambar tersebut kurang tepat, sehingga grafik yang dihasilkan juga salah. Walaupun bukti yang diberikan kurang tepat, namun siswa tetap beranggapan bahwa bentuk grafik fungsinya tetap garis lurus. Berikut hasil wawancara dengan siswa.

\begin{tabular}{|c|c|}
\hline PSS2-35 & $\begin{array}{l}\text { Jadi, hasil gambar grafikmu } \\
\text { apakah merupakan grafik fungsi } \\
\text { h(x)? }\end{array}$ \\
\hline$S S 2-35$ & : Bukan \\
\hline PSS2-36 & : Mengapa bukan? \\
\hline$S S 2-36$ & $\begin{array}{l}\text { Garisnya tidak melewati titik } \\
(\mathbf{3}, \mathbf{0}) \text { dan }(\mathbf{6}, \mathbf{4})\end{array}$ \\
\hline PSS2-37 & $\begin{array}{l}\text { Lalu, apakah dugaanmu } \\
\text { terbukti? }\end{array}$ \\
\hline SS2-37 & : Harusnya terbukti bu, \\
\hline PSS2-38 & $\begin{array}{l}\text { Apakah jika gambarmu benar } \\
\text { hasil grafiknya berupa garis } \\
\text { lurus? }\end{array}$ \\
\hline$S S 2-38$ & : Harusnya tetap garis lurus \\
\hline PSS2-39 & $\begin{array}{l}\text { : Apa yang dapat kamu simpulkan } \\
\text { dari dugaan dan buktimu? }\end{array}$ \\
\hline$S S 2-39$ & $\begin{array}{l}\text { : Hmmm... dugaan saya garis } \\
\text { lurus, terus pas dibuktikan juga }\end{array}$ \\
\hline & garis lurus. Berarti \\
\hline & $\begin{array}{l}\text { kesimpulannya kalau fungsinya } \\
\text { seperti itu grafiknya garis lurus. }\end{array}$ \\
\hline
\end{tabular}

$\begin{array}{ll}\text { PSS2-44 } & \text { Kalau saya punya soal } \\ & \text { begini, dugalah bentuk } \\ & \text { grafik fungsi } f(x)=\frac{1}{2} x+ \\ & 5 ! \\ \text { SS2-44 } & \text { : Garis lurus } \\ \text { PSS2-45 } & \text { : Mengapa? } \\ \text { SS2-45 } & \text { :Karena pangkat ini } \\ & \text { (menunjukkan variabel } x) \\ & \text { itu 1 }\end{array}$

Siswa menilai jika dugaan yang dihasilkan benar, hasil grafik yang dihasilkan juga garis lurus walaupun ada kesalahan saat meletakkan titik koordinat $(x, y)$. Siswa menilai hal tersebut tidak berpengaruh pada bentuk grafiknya, maka ia mencoba untuk memvalidasi kesimpulan yang dibuat dengan menguji kesimpulan tersebut untuk soal lain yang sejenis. Berikut adalah hasil wawancara dengan siswa saat memvalidasi kesimpulan.

\section{PENUTUP}

\section{Simpulan}

Berdasarkan hasil analisis dan pembahasan yang telah diuraikan pada bab sebelumnya, maka dapat disimpulkan sebagai berikut.

1. Penalaran Siswa yang Benar dalam Menggambar Grafik Fungsi

Siswa yang benar menggambar grafik fungs mengidentifikasi informasi/fakta tertulis pada soal. Saat mengumpulkan fakta, siswa memeriksa pangkat tertinggi dari variabel pada fungsi, sehingga ia memperoleh informasi lain mengenai jenis fungsi tersebut. Siswa menyebutkan semua informasi, mulai dari variabel, pangkat tertinggi variabel, keterkaitan variabel satu dengan yang lain dan simbol-simbol pada soal. Namun, pada siswa kedua, ia tidak menyebutkan keterkaitan antar variabel $\boldsymbol{x}$ dengan nilai fungsinya.

Siswa menganalisis fungsi dan memperoleh informasi yang tidak tertulis bahwa rumus fungsi pada soal berpola sama, karena ketiga fungsi memiliki variabel $\boldsymbol{x}$ berpangkat 1 dan sebuah konstanta.

Siswa membuat dugaan bentuk grafik fungsinya dengan mengidentifikasi jenis fungsi terlebih dahulu, setelah membuat dugaan, ia mampu menjelaskan alasan mengapa ia membuat dugaan tersebut. Siswa membuktikan dugaan yang dibuat dengan menggambar grafik fungsi menggunakan langkah memisalkan sebarang bilangan Real untuk disubstitusikan pada salah satu variabel pada fungsi. Kedua siswa memiliki langkah yang hampir sama dalam menggambar, yang membedakan hanya pada langkah awal, siswa pertama menyederhanakan fungsi terlebih dahulu, sedangkan siswa kedua tidak. Keduanya menggambar dengan cara memasukkan sebarang bilangan Real untuk menggantikan salah satu variabel, sehingga diperoleh koordinat titik yang menjadi titik pembentuk grafik fungsi.

Siswa memeriksa perhitungan dan letak titik koordinat untuk memastikan grafik yang dihasilkan tepat. Keduanya tidak menemukan kesalahan, sehingga kedua siswa bisa menyimpulkan bahwa dugaan dan buktinya tepat. Berdasarkan hal tersebut, 
siswa membuat kesimpulan "jika fungsi linear, maka grafik fungsinya berupa garis lurus”.

Siswa memvalidasi kesimpulan yang ia buat dengan menguji kesimpulan tersebut dengan soal lain yang sejenis. Setelah menguji, diperoleh hasil yang konsisten. Sehingga kesimpulan yang dibuat benar.

\section{Penalaran Siswa yang Salah dalam Menggambar Grafik Fungsi}

Siswa yang salah menggambar grafik fungs mengidentifikasi informasi/fakta tertulis pada soal. Saat mengumpulkan fakta, siswa memeriksa pangkat tertinggi dari variabel pada fungsi, sehingga ia memperoleh informasi lain mengenai jenis fungsi tersebut. Siswa tidak menyebutkan semua informasi pada soal.

Siswa yang salah menggambar grafik fungsi, menganalisis fungsi, namun tidak memperoleh informasi yang tidak tertulis pada soal. Siswa membuat dugaan bentuk grafik fungsinya dengan mengidentifikasi jenis fungsi terlebih dahulu, setelah membuat dugaan, ia mampu menjelaskan alasan mengapa ia membuat dugaan tersebut.

Siswa membuktikan dugaan yang dibuat dengan cara menggambar grafik fungsi dengan langkahlangkah rutin. Kedua siswa memiliki langkah yang hampir sama dalam menggambar, yang membedakan hanya pada langkah awal, siswa pertama menyederhanakan fungsi terlebih dahulu, sedangkan siswa kedua tidak. Keduanya menggambar dengan cara memasukkan sebarang bilangan Real untuk menggantikan salah satu variabel, sehingga diperoleh koordinat titik yang menjadi titik pembentuk grafik fungsi. Namun, saat menggambar kedua siswa mengalami kesalahan, siswa pertama salah dalam perhitungan sedangkan siswa kedua salah saat meletakkan titik koordinat $(\boldsymbol{x}, \boldsymbol{y})$ pada bidang kartesius.

Siswa memeriksa perhitungan dan letak titik pada bidang kartesius untuk memastikan grafik yang dihasilkan tepat. Keduanya dapat menemukan kesalahan dalam langkah menggambar grafik fungsi ini, namun kedua siswa menilai kesalahan ini tidak berpengaruh pada bentuk grafik fungsinya, sehingga ia tetap menyimpulkan bahwa grafik fungsi linear adalah sebuah garis lurus.

Siswa memvalidasi kesimpulan yang ia buat dengan menguji kesimpulan tersebut dengan soal lain yang sejenis. Hasil validasi siswa kurang tepat karena kesimpulan yang dibuat keliru.

Saran

Berdasarkan hasil penelitian di atas, maka disarankan beberapa hal sebagai berikut.

1. Dalam proses pembelajaran materi menggambar grafik fungsi, sebaiknya siswa diajarkan menggambar grafik fungsi dengan cara mencari titik potong sumbu $\boldsymbol{x}$ dan $\boldsymbol{y}$ dan tidak hanya dengan cara memasukkan sebarang nilai pada variabel fungsi, sehingga hal ini akan mempermudah siswa saat mencari himpunan penyelesaian dan tiitk pembentuk grafik fungsi linear.

2. Subjek pada penelitian ini yaitu berjenis kelamin perempuan, sehingga disarankan untuk penelitian selanjutnya yang serupa sebaiknya menggunakan subjek berjenis kelamin laki-laki untuk melihat perbedaan proses berpikir siswa perempuan dan lakilaki dalam menggambar grafik fungsi.

\section{DAFTAR PUSTAKA}

Anderson, L.W.,\&Krathwohl, D. R. 2001. A Taxonomy for Learning, Teaching, and Assessing: A Revision of Bloom's Taxonomy of Educational Objectives: Abridged edition. New York: Longman.

Ardhana, Tandyo. 2017. "Keterampilan Berpikir Siswa dalam Menyelesaikan Soal Garis Dan Sudut Berdasarkan Taksonomi Bloom Revisi", (Online),(http://eprints.ums.ac.id/56887/20/NASKAH \%20PUBLIKASI.pdf, diakses 22 Januari 2018).

Ball, D.L\&Bass, H. 2003. Making Mathematics Reasonable in School. A Research Companion to Principles and Standards for School Mathematics. Reston, VA: National Council of Teachers of Mathematics.

Brodie, Karin. 2010. Teaching Mathematical Reasoning in Secondary School Classroom. New York: Springer

Brookhart, S. M. 2010. How To Assess Higher Order Thinking Skills in your Classroom. Virginia USA: ASCD Alexandria.

Copi, I. M. 1978. Introduction to Logic. New York: Macmillan

English, Lyn. 2004. Mathematical and Analogical Reasoning of Young Learners. London: Lawrence Erlbaum Associates Publisher.

Fatimah, N. 20017. “Analisis Kesalahan Menyelesaikan Soal Persamaan Garis Lurus". Makalah seminar disajikan dalam eprints.ums.ac.id/48690/ diakses pada $\underline{13 \text { Maret } 2019}$ 